\title{
The Limitation of Translatability Between English and Chinese
}

\author{
JIN Zhao-hui \\ University of Shanghai for Science and Technology, Shanghai, China
}

\begin{abstract}
Translation is not only an exchange activity among languages, but also a process about transformation and communication of culture. Language and culture is a unity that language is the essential part of culture while culture is the nature and content of language communication. Because of its own history and distinctive geographical environment, culture has its unique ethnic features and psychological construction. All of these culture elements reflect on language. For different languages, there are great differences about the glyph, sound, words, rhetorical devices, and idioms. Such differences in language and culture between English and Chinese can cause the limitation of translatability in the process of translation.
\end{abstract}

Keywords: translation, language, culture, limitation of translatability

\section{Introduction}

Translation is an activity that crosses language and culture. Language is the carrier to transfer culture while culture is the core of language. By changing the language of one form to another, translation reaches equivalence in meaning and style of two languages to assure the massages be understood by target language readers. Thus, in the process of translation, the consideration about language itself and culture elements is the essential part when people try to solve the problems occurring in translation.

In practice of translation, translator faces double difficulties-language and culture; it is hard to be faithful and elegant at one time. British translator Peter Newmark (2001) considered perfect, idealistic or correct translation does not exist. Translation is not likely to represent the meaning and style of the source text perfectly.

There are discussions about the limitation of translation for a long time. People who hold the view of the impossibility of translation insist that the difference between languages is not the difference between language symbols, but the different views of the world. Language is the outer appearance of ethnic spirit and plays a main role in guiding the inner world. For these people, translation is to solve an unsolvable issue. It is impossible to change or translate people's view of world from one language to another.

The language and culture differences to a large extent prevent the translation work. In the practice of translation, we usually find some problems hard to solve, such as lack of target language words, the unique history of both nations, the special understanding of a certain image, and so on. Translation has limitations in transferring one language to another or one culture to another. By analyzing such limitations, we may expect to improve the translation work to a higher level.

JIN Zhao-hui, Master of Arts, lecturer, College of Foreign Languages, University of Shanghai for Science and Technology, Shanghai, China. 


\section{Relevant Researches on Limitation of Translatability}

The limitation of translatability is an important issue discussed in translation theory. Linguistic theoreticians first proposed the idea of limitation of translatability in Western translation theory. In the practice of translation, there must be loss of messages in communication, so the limitation of translatability is the permanent phenomenon in the transfer of languages.

British linguistics Cartford (1965, p. 94-99) said "actually, translatability is gradually changed but not definitely defined. The unit or text of source language is more or less translatable, and absolute translation or impossible translation does not exist". He divided untranslatability into language untranslatability and cultural untranslatability. On language part, untranslatability means that it could not find substitute words or semantic forms in target language. On cultural part, untranslatability refers to the lack of equivalent images or relative factors that could be compared to source language.

Nida (1993, p. 64) pointed out "when the expressive form of a message is its actual meaning, it is difficult to translate this meaning from one language to another language. Such case usually could not be translated". Chen Deng (1996) expounded on the untranslatability from language and culture aspects. But these difficulties could be surmounted by the improvement of translators. With other translators, they have similar view that "faithfulness" is relative and hard to achieve.

Combing the researches at home and abroad, it is apparently that translation theoreticians have many difficulties in the practice of translation. Some could be solved by the efforts of translators while some could not be translated completely. Equivalence and faithfulness are the standards of translation, but how to realize them is the problem in the practice. Many factors cause translation problems and block translation.

\section{Differences Caused by Language Itself}

Language has its own classifications and its unique culture contents that distinguish one from another. English belongs to Indo-European languages and Chinese belongs to Sino-Tibetan languages. The huge differences between these two language systems arouse difficulty in the process of a pure translation. Such differences could be found in construction, phonetic and semantic aspects.

\section{Limitation of Translatability Caused by Glyph Differences}

Chinese character is pictograph. Its unique construction is especially flexible in taking-apart or combination of words and it is hard to express in another language. For example, if we add some element to the character “女”, which means “female”, to reconstruct a new character, such as “婚”, “姻”, “好”, “妇”, and so on, it is hard to exactly explain and translate in English.

On the other side, English is consisted by letters, which are meaningless in the glyph. We cannot infer the meaning of a word only by the combination of letters.

Chinese characters are well-proportioned in construction, beautiful and generous, and could stimulate infinite imaginations. English words are constructed with letters according to pronunciation principles. So, if Chinese characters are translated into English, the meaning and content maybe well-transferred, but the beauty of glyph may be lost and could not be translated. At the same time, when English is translated into Chinese, the special letter combination form will lose unique content.

\section{Limitation of Translatability Caused by Phonetic Differences}

Each language has its distinctive phonetic system. Languages in the world can be classified as tone 
languages and atonal language. Chinese is a single-syllable language with four tones, which are used to show different meanings. In ancient times, there were poems composed of sentences each of which contained five words or seven words with strict parallelism and rules about rhythm and tones. In English, there are not such tones, but only stressed and unstressed accents. English is a language, in which a word contains one, two, or multiple syllables. The pronunciation rules of Chinese and English are also totally different. Meanwhile, the dialect factor is influencing the translation as well.

Chinese ancient literature works are the most glorious and amazing creation, including poems, essays, and dramas. All of these works are meaningful in content, strong in rhyme, and beautiful in pronunciation. In phonetic aspect, there is an obvious phenomenon that Chinese ancient literature works are full of additional words that strengthen the rhythms, like “兮”, “哉”, “也”, “矣”, “了”, and so on. Such words often appear repeatedly at the end of every sentence in the whole poem. Here is the example about the word "了" from a poem in A Dream in Red Mansions.

好了歌
世人都晓神仙好, 惟有功名忘不了!
古今将相在何方? 荒冢一堆草没了!
世人都晓神仙好, 只有金银忘不了!
终朝只恨聚无多, 及到多时眼闭了。
世人都晓神仙好, 只有娇妻忘不了!
君生日日说恩情, 君死又随人去了。
世人都晓神仙好, 只有儿孙忘不了!
痴心父母古来多, 孝顺儿孙谁见了?

The English translation version of Yang Xianyi and Dai Naidie is:

All good things must end

All men long to be immortals

Yet to riches and rank each aspires

The great ones of old, where are they now?

Their graves are a mass of briars

All men long to be immortals

Yet silver and gold they prize

And grub for money all their lives

Till death seals up their eyes

All men long to be immortals

Yet dote on the wives they've wed

Who swear to love their husband evermore

But remarry as soon as he's dead

All men long to be immortals

Yet with getting sons won't have done

Although fond parents are legion

Who ever saw a really filial son?

Through the whole text, there is no such musical sound and rhythm as in the source language. In such case, even we have translated the poem's meaning and style, the beauty of sound and rhythm is hard to match. 
In English, "alliteration" always makes the language more powerful and musically beautiful to get its effects of humor or irony. For instance, in "it was a splendid population-for all the slow, sleepy, sluggish-brained sloths stayed at home...." by Mark Twain, the five continual "s" vividly expressed the disgusted feeling of the author. However, such combination of construction, sound, and content could not be completely reflected in target language.

\section{Limitation of Translatability Caused by Semantic Meaning}

Chinese is a language that shows its meaning from the words' appearance and sound while English distinguishes its meaning through pronunciation and combination of letters. The problems caused by construction of a character and its phonetic feature affect language's meaning, and could be the limitations of translation. What is more, the differences between Chinese and English on the meaning of words and the rhetorical devices also stand in the way in the practice of translation. It is hard to get the meaning of words fully translated while reserving the original forms and constructions in whole context.

In the practice of translation, "If translation could not present the rhetorical devices, it could not faithfully express the content, thoughts and style of source text, even if the general meaning has been achieved, the language affecting power has greatly reduced". Due to the differences of words' matching and scope, non-parallelism of words, and different rhymes between English and Chinese, there are different rhetorical devices in expressing one concept, which limits translation.

For example, in A Dream in Red Mansions, there is a Chinese folk wisecrack. “我那里管的上这些事来! 见识又浅，嘴又笨，心又直，人家给个棒槌，我就拿着认针（真）了”.

Translated in English, it is "I am incapable of running things. I'm too ignorant, blunt and tactless, always getting hold of the wrong end of the stick. And I am so soft-hearted, anyone can get round me".

In Chinese, the phrases “认真” and “认针” are of the same pronunciation but different meanings. When translated into English, we cannot find the same pronunciation of words that could exactly explain the wisecrack.

Here is a dialogue of another example from English.

A: why is the river rich?

B: Because it has two banks.

Translation A:

$\mathrm{A}$ : 为什么说河流很富裕?

B: 因为它有两个河岸。

Translation B:

$\mathrm{A}$ : 为什么说河流很富裕?

B: 因为它有两个银行。

The source text bears a kind of humor and wisdom and the English readers could easily understand what it means. But translated into Chinese, it is hard to understand the meaning or the humor.

\section{Limitation of Translatability Caused by Culture}

Translation is not a task that solely involves language. It is also the mutual understanding of different cultures. Thus, the culture differences have great influences on the translation practice. Language and culture could not be divided into two separate parts, as language is a part of culture and the embodiment of the culture. So, translation is not only language exchange, but also the culture transfer and exchange. 
Due to respective geographical environment, history and literature development, religious belief, views about the world, and customs, cultures of different nations demonstrate great differences. And these huge differences affect translation task.

Cultural lexical gap. Lexical gap refers to many new words or specialized words and phrases in source language that could not find the equivalent expressive forms in target language. The great differences between Chinese and Western culture provide a great blank of the equivalent words in two languages. We know that translation is possible because of the existence of "channel for message transferring". When the image from the source language could not find the same or similar image in target language, the target language readers have difficulty to know what the source language means.

For example, the relative members in Chinese is really complicated and it has the whole system of appellation in which “外公外婆，爷爷奶奶，舅舅舅妈，伯父伯母，堂兄弟姐妹，表兄弟姐妹，姨妈姨父， 叔叔阿姨，姑姑婶婶，and 岳父岳母” are explicitly and strictly defined. But in English, there is no such system, which will cause the limitation of translatability to some extent.

Unique literary quotations. Both Chinese and English have profound cultural background. Chinese literature, with its glorious fruits, to name just a few, the four ancient masterpieces, ancient poems, historical records, five classics, and so on, has always been the treasures in its culture. The same condition is to English literature. Byron and Shakespeare enjoy the worldwide prestige.

There are many quotations from the two literary treasuries and they are still in people's daily life or art works. For example, Tang Xuanzang's pilgrimage, the endurance the king of Yue state, Hamlet's hesitation, and revenge, etc. are all featured by the two culture's unique cultural cores.

It is not that these works could not be translated. What is important is that literary works are full of such cultural codes as quotations, anecdotes and other ancient elements, and so on. In the translation process, it is hard to translate completely and perfectly without some additional explanation.

\section{Strategies Dealing With Limitation of Translatability}

There are so many differences between the two languages and cultures, limiting the translatability in both C-E and E-C translation. However, these untranslatable parts still have the possibility to be translated. The methods that overcome limits of translatability lie in the purpose of the translation work and the reader's response to the translation. Only if translation has the same effect on readers as the source text has on the source language readers, the translation would be more or less getting its results. As referred by Nida (1993, p. 1) "the new focus, however, has shifted from the form of the message to the response of the receptor". Absolute translatability is impossible while it can be improved when we employ some methods to achieve the receptor's response.

\section{Zero Translation}

This method is applied to deal with the limits of translatability on lexical level. Some of these concepts could be directly put in translation without any change. For example, Jiaozi (饺子), Zongzi (粽子), Kungfu (功 夫), Xifu (师傅), and so on. These words have been accepted by more and more people and have merged into the target language. As the development of communication, more and more words will be translated in this way. The limitation of translatability caused by lexical gap becomes less and less. 


\section{Substitution of the Target Language Images}

Following the translation theory of Nida and Newmark, in the practice of translation, it is necessary for target language readers understand, accept, and have the same feelings and emotions about the translation. Explanation of the semantic and rhetorical level means that translation should involve in the target language images and comply with the customs and similar images of target language. So, the target language readers could easily understand the source language images.

For example,

(1) 济公劫富济贫, 深受穷苦人民爱戴。

Jigong, Robin Hood in China, robbed the rich and helped the poor.

(2) A: why is the river rich?

B: because it has two banks.

A: 为什么河流富有?

B：因为年年有鱼啊！

\section{Foreignization With Explanations}

Differences in culture always make translation impossible and difficult to understand. It is necessary to explain what the special terms mean and add some footnotes on the following context. For example, a selection of classical Chinese essays from Guwen Guanzhi, A Dream in Red Mansions, the English Bible are all translated with many explanations and additional notes that could assist target language readers' understanding. With the additional explanation, readers have better understanding about the original literary works.

This method keeps information and style of the source text as possible as it can, and lets readers read more easily and conveniently. It is a good and practical way to solve the problems resulting from differences of language and culture.

\section{Conclusion}

There are many linguists and translators regarding complete and absolute translation as an impossible task since the differences of languages and cultures are hard to avoid. But with the improvement and development of the theory and practice of translation, it is clear that sound translation still can be achieved. With the development of language, the update and advancement of science and technology, communication between Chinese and English languages and cultures has increased dramatically. The more we communicate, the easilier we understand each other. The study of the limits of translatability not only benefits translators, but also readers. It helps improving the quality of translation and assuring readers' better understanding of the source text and culture.

\section{References}

Catford, J. (1965). A Linguistic Theory of Translation. Oxford University Press, London. Chen, D. (1996). 翻译中的可译性限度. China: Foreign Language Education (1), 70-73.

Feng, Q. H. (2003). 实用翻译教程. China: Shanghai Foreign Language Education Press. Han, F. (2004). Untranslatability in translation practice between Chinese and English. China: Shanxi University.

Jiang, Y. G. (2002). A tentative study on translatability and untranslatability with specific reference to language and culture.

China: Foreign Language College of Tianjin. Jin, L., \& Zhu, S. H. (2004). 论翻译的不可译性. Journal of Zhaotong Teacher's College, 26(6).

Liu, C. Z. (2000). 可译性的语言功能观. Chinese Translators Journal, (1), 31-34. 
Liu, M. Q. (1999). 当代翻译理论. China: Translating and Publishing Corporation.

Luo, J. G. (2005). A selection of classical Chinese essays from Guwen Guanzhi. China: Foreign Language Teaching and Research Press

Munday, J. (2001). Introducing translation studies: Theories and applications. Routledge, London.

Newmark, P. (2001). Approaches to translation. China: Shanghai Foreign Language Education Press.

Nida, E. A. (1993). The theory and practice of translation. China: Shanghai Foreign Language Education Press.

Wang, B. (2001). 论不可译性. Chinese Translators Journal, (5), 8-16.

Yang, M., Wang, K. Q., \& Wang, H. Z. (2003). An outline of the traditional Chinese culture. China: Press of Chinese Ocean University. 